\title{
Analysis of the Interpretation of the Meaning of the Karampuang Traditional House in Sinjai Regency
}

\author{
Kasdiawati ${ }^{1}$, Jeanny Maria Fatima ${ }^{2}$, Muhammad Farid ${ }^{3}$ \\ 1,2,3 Universitas Hasanuddin, Indonesia
}

\begin{abstract}
Karampuang traditional house is one of the cultural heritages that have symbols and meanings believed from generation to generation. This study aims to determine what symbols are contained in the Karampuang traditional house, both verbal and non-verbal, and to analyze the symbols. This research used a qualitative method in which the data were collected by using some techniques including observation, in-depth interviews, documentation study, literature study, and field notes. The study used two data sources, primary data, and secondary data. The technique of determining informants in this study was the purposive sampling technique. There were six informants. A traditional house consists of two houses. There are two renowned traditional houses, to wit; Arung and Gella. Arung's house faces West, while Gella's traditional house faces East. The Roof of the house has two layers with a timpa laja' in three layers. The roof Gella's is not double-decked and two-tiered; while the Arung's composed of three of the timpa laja. In regard to the Islamic symbols in traditional houses, the houses are constructed with 30 house poles, as a symbol of the number of juz in the Quran. The 5 poles running north to south symbolize the 5 pillars of Islam; while 6 poles from west to east are a symbol of the six articles of faith. The ladder of the Karampuang traditional house only has one ladder with odd steps which the position is different from the house in general.The door of the house is located in Elle 'ri olo, which is parallel right against Salima'. Above the door, there is a stone that functions as a counterweight so that the door can be partially or completely open. The floor of a house made of bamboo is also called salima as a symbol of the rib which stretches from north to south called tunebbe'. The kitchen is located at the front that can be clearly seen when climbing the house's ladder; in front of the door is a kitchen with two stoves located.
\end{abstract}

Keywords: Karampuang, Meaning of Interpretation, Nonverbal, Symbol.

This is an open access article under the CC-BY-NC license.

\section{INTRODUCTION}

Cultural diversity is really essential that cannot be torn apart from the Indonesian community. Besides the diversity in the scope of both culture and ethnicity, Indonesia consists of various territorial customs and regional cultures in each area. Karampuang custom is one of the cultures located in Dusun Karampuang Tompobulu, Kec. Bulupoddo, Kab. Sinjai, Province of South Sulawesi.

The history of Karampuang cannot be separated from its sudden presence in Manurung from the top of a hill. The name itself is originated from the local language Karampuang, which means Goosebumps. After the first Manurung disappeared which was suddenly replaced by the second Manurung, who lost seven people, one of whom was a woman. This woman later became the leader in Karampuang. Karampuang has two traditional houses. The traditional house is inhabited by Arung as the highest leader in an adat and the house that is dwelled by Gella as the person in charge of running a regular government.

The Karampuang traditional house has symbols full of meaning passed down from generation to generation. Researchers aimed to see the symbols contained in the Karampuang Traditional House, both verbal and nonverbal, and interpret the meaning of these symbols. As a traditional house, its shape cannot be cut apart from the meaning because it is integrated into the symbol of the function of the house itself. Meanwhile, the Karampuang community considers the house has various functions, including social function, economic function, and religious function that portrays symbols including symbols of Islam. 
Communication and cultural studies are closely related. This is due to the cultural studies that are formulated, shaped, transmitted, and learned through communication. The human ability to communicate can create knowledge, symbolic language, values, and ceremonial rules that impose boundaries in the society where the culture occurs. Culture and communication are inseparable;

therefore, culture does not only determine the person who encodes the message but also the meaning that he/she is trying to confess by considering the conditions for sending and how the massage is interpreted. All of our behavioral variables are greatly dependent on the culture where we grew up. Consequences are the foundation of communication, various cultural values, and various communication practices.

\section{LITERATURE REVIEW}

This research, considered from the perspective of communication science, is about the meaning of the message or the interpretation of the message defined in the Karampuang Traditional House, both through verbal and non-verbal context. To strengthen this research, below are some results of the relevant researches to this present research.

Heri Jauhari conducted research in 2018 with a title "Makna Dan Fungsi Upacara Adat Nyangku Bagi Masyarakat" (The Meaning and Function of the Nyangku Traditional Ceremony of the Panjalu Community). Panjalu, a village that used to be dwelled by Panjalu kingdom, still holds the tradition of the Nyangku traditional ceremony. The Panjalu people consider this tradition sacred because it is related to the origin of the existence and spread of Islam in the Panjalu kingdom and the Priangan Tatar. The heading event is the traditional ceremony of Nyangku religious lectures (Islam), cleaning of sacred objects, and several other series of events. The results of the data analysis found that the traditional ceremony of Nyangku has functions of ritual, social, education, and religious tourism, which of the four functions, the ritual function is the most dominant. Furthermore, the Nyangku traditional ceremony means literal/historical, allegorical, topological/moral/educational, and anagogical, which the historical meaning has the highest intensity of all those meanings.

Next, a research conducted by Ryan Prayogi, et all with the title of the research Pergeseran Nilai-Nilai Budaya Pada Suku Bonai Sebagai Civic Culture di Kecamatan Bonai Darussalam Kabupaten Rokan Hulu Provinsi Riau (The Shifting of Cultural Values of the Bonai Tribe as Civil Culture in Bonai Darussalam District, Rokan Hulu Regency, Riau Province) shows that the cultural values of the Bonai tribe are shifting. Based on the beliefs of Bonai Tribe's culture, there are cultural values perceived as the life principles of the Bonai Community which customs are upheld by the indigenous people as a life cycle that is made as guidelines and rules that must be obeyed by tribal communities, including birth, Prophet's Sunnah, occupation, education, marriage, community leadership system, and death.

Hidayatullah, researching "Analisis Makna simbolik Budaya Sadaka Masyarakat Dewan Adat Gorontalo" (the Analysis of the Symbolic Meaning of the Sadaka Culture of the Gorontalo Customary Community Council), examined the culture of Sadaka by concerning the stages of Sadaka submission, which reveal the existing symbolic meanings and community responses. This research uses a qualitative approach.

Furthermore, a research conducted by A. Wiwi Pratiwi Puji Lestari, with the title Makna Simbolik dalam prosesi Mattompang Arajang di Kabupaten Bone (Symbolic Meaning in the Mattompang Arajang procession in Bone Regency), focused on the meaning contained in the Mattompang Arajang ritual, which is a form of mutual respect for one another in social life, cleansing oneself and not looking down on fellow living creatures created by God. All of those researched described examine symbolic meaning with a qualitative research approach, ethnography, and so on. Therefore, this current research examines the symbols and meanings of messages contained in the Karampuang culture, which includes the analysis of the aspect of message interpretation, which has not been conducted in previous researches. The term of interpretation can refer to the ongoing process of interpretation or its results. 
An interpretation can be part of a presentation or depiction of information that is modified to suit a specific set of symbols. This information can be in the form of spoken, written, pictorial, mathematical, or various other forms of language. Besides, interpretation is an explanation, meaning, impression, opinion, or theoretical view of an object that comes from deep thinking and is strongly influenced by the background of the person who interprets it. Every object, whether books, poetry, sculptures, paintings, data, or others, can become an object of interpretation. Interpretation is usually made to get a clearer and deeper understanding or knowledge about something. In regard to this point of view, it can be inferred that the research objective of this present study is to find out what symbols are contained in the Karampuang traditional house, both verbal and nonverbal, and to be further analysed by especially concerning on the aspects of communication and culture that are believed having a great influence to the existence of the Karampuang Traditional Houses.

Considering how strong the relationship between culture and communication, Hall (1960) in Liliweri 2005; 361 states that communication is culture, and culture is communication. Hall said that only cultured humans communicate, and when humans communicate, they are influenced by their culture. Humans state and may also interpret their culture to others, or another way around that is other people could interpret their culture. Culture provides guidelines so that we can initiate communication, including interpreting messages.

In line with Clifford Geertz in Alo Liliweri 2005: 362, Greetz strived to understand the human culture in the context of intercultural encounters by utilizing an interpretive approach. Interpretation towards culture is generally a symbolic interpretation, and it is none other than a system of meaning related to culture. Thus, interpretation of culture, according to Geertz, is essential only through semiotics.

Quoting Marx's statement in Alo Liliweri 2005: 362, Geertz stated that humans are symbolic creatures. Humans analyze culture through scientific experience, then meet it with the applicable laws. Subsequently, he interprets culture through investigating the meanings of the culture that can be communicated by way of the cultural communication process. Human behavior, including cultural communication behavior, can be viewed as symbolic actions, such as voice stress in conversation, colors in pictures, lines in writing, music rhythm, all of which have to do with how cultural patterns are arranged in a frame.

Clifford Geertz, regarding the work of the anthropologist Kluckholn in Alo Liliweri 2005: 365 assumes that culture is like a "Mirror For Men", so he advocates the interpretation of the cultural meaning as (1) the whole view of human life; (2) a social inheritance owned by an individual from a group; (3) ways of thinking, feeling and believing; (4) abstraction from behavior; (5) how a group of people expresses their behavior; (6) a shopping center building; (7) a standardized orientation unit to solve various recurring problems; (8) learned behavior; (9) a mechanism for regulative regulation of behavior; (10) a set of techniques for adapting to other environments and other people; (11) layers or deposits of human history; and (12) behavior maps, behavior matrices and behavior filters. It can be concluded that culture, including socio-cultural conditions, the state of cultural psychology, affects the ways a person communicates.

The use of meaning does not seem easy, this is due to several factors, which are the meaning in a sentence that may be different depending on the cultural context or the sentence use, and the meaning in a word or sentence that depends on the difference in signs in a particular event which the meaning given is not permanent.

Petada (2001) in Sobur (2003: 122) further revealed that signs produced by humans are also differentiated into verbal and non-verbal ones. Verbal is a sign that is used as a means of communication 
produced by a speech instrument, while non-verbal ones include: signs that use limbs, followed by symbols and objects that have cultural and ritual significance.

Littlejohn (2017) expressed that signs are the basis of all aspects of communication. Humans with intermediate signs can express any message and communicate with anyone. In this context, it is commonly referred to as a nonverbal message.

Mark L. Knapp (1972) mentioned five functions of nonverbal messages concerning verbal messages. The first is repetition or repeating the ideas presented. The Second is a substitution, which replacing verbal symbols. The third is a contradiction, rejecting or giving another meaning. Next, complement, namely completing and enriching meaning, and the last is emphasizing the message called accentuation.

The author of the Nonverbal Communication System, Dale G. Eaters (1976), mentioned six reasons for the importance of nonverbal messages. Firstly, it determines what to mean. According to Mehrabian, author of The Silent Message estimates a 93\% impact on nonverbal messages. Secondly, non-verbal communication conveys emotions and feelings. Thirdly, the conveyor of meaning is relatively free from ambiguity because the message can be strengthened. Next, the function of metacommunication of nonverbal communication is to provide additions that clarify the meaning of the message. The fifth, it is very efficient, and the last is as a means of suggestion, something implicit (implicitly). Symbols are part of human life, where there are three things that humans can do about symbols (Littlejohn, 2017); first, humans create symbols to give names to make objects and situations. Second, humans use symbols to communicate. Third, humans misuse symbols to take advantage of symbols by abusing them when they are in unfavorable circumstances. Various communication events always involve the use of verbal and non-verbal symbols simultaneously. Verbal and nonverbal language have a holistic nature (each is inseparable). In many communication activities, nonverbal language complements verbal language, or nonverbal language is an explanation of verbal language. Verbal messages are all kinds of symbols that use one or more words. Almost all speech stimuli that we are aware of fall into the category of deliberate verbal messages to wit conscious attempts to relate to other people verbally (Mulyana, 2003). Important elements in verbal communication can be words and language.

\section{RESEARCH METHODOLOGY}

This type of research is qualitative, whose presentation is in a qualitative descriptive form. A qualitative approach is a process of research and understanding based on the methodology that investigates social phenomena and human problems. In this approach, the researcher creates a complex picture, examines words, reports a detailed view of the informant, and conducts studies on natural situations (Creswell, 2007). This research was conducted in Dusun Karampuang, Desa Tompobulu, Kec. Bulupoddo, Kab. Sinjai. Research informants were people who knew profoundly about Karampuang customs and were expected to be able to provide explanations as required in this recent research; besides that, the informant involved were considered to have known about the problem under study. Other informants were the Customary Apparatus, residents in the Karampuang customary area, as well as the Department of Tourism and Culture, Kab. Sinjai. The technique of determining the informants in this study was using the purposive sampling technique. That the researcher determined the sample to be taken under certain considerations by following the requirements or research objectives to obtain required and accurate data. In this study, informants were selected based on certain considerations, one of which was those who were considered capable of answering questions related to the Karampuang traditional house. Data collection was carried out after the researcher determined the problem to be studied. In further, the research on the symbolic meaning of the Karampuang traditional house employed two data sources, primary data, and secondary data. The interview was carried out with predetermined informants. In addition to making observations, the researcher also conducted interviews with informants who knew the problem being investigated. The interview was a technique for approaching sources of information using question and answer done systematically and based on research objectives. Data analysis 
techniques in this study used qualitative methods so that the analysis technique used was interpretative understanding in three ways; 1 . Data reduction; as a process of analysing data to reduce and summarize the results of research on things that are important to the researcher, aims to provide a more detailed picture. 2. The presentation of data in this study began with interviews and/or a series of other data collection processes on research subjects. 3. The existing data was reduced or selected according to the data that was considered important, which was then continued by obtaining the appropriate data. The data was presented to be analysed and compiled by following the existing problem formulations in a brief, clear, and detailed but comprehensive manner. If the data analysis is carried out and finds an interactive relationship, the data will be obtained accurately.

\section{FINDING AND DISCUSSION}

The informants in this study consisted of people who were considered capable of providing the necessary information related to this current research. Some of them came from the Karampuang customary institution, some were Karampuang residents as descendants of traditional leaders who have served in Karampuang, and the others came from elements of the Sinjai District Government.

The personal data profiles of informants in this study are as follows:

The first informant is Mr. Tola, 75 years old. He is a customary stakeholder with a position as Arung (To Matoa). Arung in the Karampuang traditional structure of an organization is the highest leader and is fully responsible for all activities or rituals for the ancestors. In daily life, Arung occupies the traditional house of Arung as one of the Karampuang traditional houses located in the Karampuang customary area. The second informant is Mr. Mangga, 67 years old as the Karampuang customary stakeholder who occupies Gella's house, the other type of Karampuang traditional house. In the structure of the Karampuang customary institution, Gella is likened to the prime minister who manages the regular government in everyday life. Several matters under the Gella's responsibility are related to agriculture, general matters, and internal and external Karampuang customs.

The third informant is Mr. Kasyong, 60 years old. He received the title of a Guru (or literarily means teacher) in the structural organization of Karampuang Custom, who has a role in regulating matters related to the fields of education and arts.

The fourth and the fifth informants are Haris (36 years old) and Yahya (37 years old). Both are the grandsons or descendants of one of the Arung (To Matoa) who had once ruled in the Karampuang area. The sixth informant is Yuhadi Samad, 45 years old, who serves as Head of the Department of Tourism and Culture of Sinjai Regency. The Department of Tourism and Culture of Sinjai Regency is a regional device that has the main task and function of caring for and preserving culture in Sinjai Regency.

Data collection for this research was conducted from November 2020 to March 2021. Researchers will describe the findings of the data obtained from each informant and field observations as follows:

The Karampuang traditional house, besides functioning as a residence for customary leaders, also has social functions for its supporting communities, including as a center for the implementation of the Mappogau Hanua traditional party (one of the village parties), which is usually held in Shawwal every year as well as other traditional events such as sitting together after the field harvest is complete or as a place of massikiri 'or dhikr for residents at particular times.

In the Karampuang traditional house, both To Matoa and Gella's inhabitants, there is a carving carved on one of the poles located in the middle of the house or called posi 'Bola. The carvings carved into the Posi' Bola are called the poto' of the prophet or the knot of the prophet. The carving is an equilateral square with an unbroken circle. The pole, as posi' bola, is wrapped with a sheet of white cloth above the carving of the prophet's poto'. It is not known exactly where the carving of the prophet's poto. Arung as the 
highest leader in the Karampuang customary institution explained that only certain people could complete the carving of the prophet's poto'.

\section{In the Karampuang traditional house, inhabited by To Matoa or Arung, there is Lontara Karampuang. Lontara Karampuang is a very sacred symbol.}

It keeps a history of Karampuang and contains the Karampuang customary law. Due to its sacredness, Lontara Karampuang is neatly stored in the Karampuang traditional house in which not just anyone can access it. Lontara Karampuang is only shown at certain times, usually in a special ritual. Nonverbal messages in the form of signs and symbols play an important role in human life, even though we sometimes do not realize it. Whether consciously or unconsciously, with or without intention, someone sends and receives nonverbal messages. Even someone makes judgments and decisions based on these nonverbal messages. The nonverbal message tells someone how to interpret the other messages contained in it. We can see the nonverbal symbols in the Karampuang traditional house in some parts of the Karampuang traditional house, as follows:

House Shape. House, in South Sulawesi, are generally rectangular. This particular shape of a house can also be found in the traditional Karampuang house, which is square and has only one door. The two Karampuang traditional houses, although different in size between the Arung traditional house and the Gella traditional house, have the same shape, which is a square. The shape of a traditional square house cannot be separated from the views or life philosophy of the Karampuang community to wit the sulapa appa element or the four cardinal directions, which are elements in life; north, south, east, and west.

\section{Home Direction.}

As previously explained, the Karampuang traditional house consists of two houses, Arung and Gella, located in the Karampuang customary area, which is about 50 meters away from each other, marked with arranged stones. The traditional house occupied by Arung faces the West, which is the direction of the Qibla for Muslims' while the traditional house occupied by Gella faces east which means life. This can be related to Gella's position in government, analogized as the prime minister who regulates and makes decisions in the government or customary institutions of the Karampuang. In other words, Gella is in charge of regulating everything related to the lives of Karampuang community regarding the economy, welfare, and everything dealing with worldly life. From the direction of the two Karampuang traditional houses, both those inhabited by Gella and those inhabited by Arung, have opposite directions. Arung's traditional house faces west as a symbol of the afterlife, while Gella's faces east as a symbol of world life. It can be interpreted that ancestors in Karampuang, since time immemorial, have always maintained a balance between life and the hereafter. Thus, they do worldly activities every day, but they never forget to carry out their obligations as provisions in the next life.

\section{Roof.}

The Karampuang traditional house inhabited by Arung has a double roof with three layers of timpa laja'. Unlike the Karampuang traditional house of Gella, the roof is not tiered and the timpa laja is only two tiers. Apart from the double-decker roof and three-tiered of timpa laja' as a sign of Arung's house, another sign can be indicated with the top of the ridge. There is a wooden decoration which is an icon of a buffalo horn which is symbolized as the crown of the king. On the left and right side under the roof are carved decorations. This decoration is symbolized as earrings worn by women. The material used for the roof comes from thatch. Regarding those symbols mentioned above, it is found that the meaning of the traditional house of the king or Arung as the highest leader in the Karampuang custom can easily be identified with a roof with two layers and three layers of timpa laja '.This makes a difference from the house where Gella lives. Apart from the double-decker roof and three-tiered timpa laja 'as a sign of the Karampuang traditional house inhabited by Arung, we can find other markers at the top of the ridge.

There is a wooden decoration which is an icon of a buffalo horn which is symbolized as a crown. On the left and right under the roof are carved decorations. This decoration is symbolized as earrings worn by 
women. The existence of the earring symbol further explains that the Karampuang traditional house, which has been inhabited for generations, cannot be separated from the symbol of women. The Karampuang indigenous people believe that the second To Manurung appeared as many as seven people, one of which was a woman who later became a respected leader in the Karampuang area at that time. As an expression of appreciation, love, and affection for their leaders, the traditional house used for generations was built and shaped to include women's symbols.

Under the roof, there is a space called a rakkeang. Rakkeang for Karampuang community is a place for storing rice and tools used for farming or gardening. The rakkeang in the Karampuang traditional house is a place to store rice from freshly harvested to ten-year-old rice. The people of Karampuang appreciate rice as the incarnation of Sangiasseri or the Goddess of Rice. Their ancestors believed that Sangiasseri was the To Manurung. It is even written in Even in Lontara Karampuang about the history of rice and how to treat rice from planting to storing rice seeds.

\section{Home Pole.}

According to the history of Karampuang traditional house, it has undergone several changes in shape. Along with the entry and development of Islam in the mountains, the Karampuang traditional house cannot be separated from the influence of Islam. The initial form of the house is called langkeang, having one pole, which then developed into a traditional house with three poles, then later it becomes the current form of the house with the Islamic symbols on its poles. We can find these Islamic symbols on the number of house poles, 30 poles symbolizing the number of juz in the Quran. There are 5 poles that stretch from north to south as a symbol of the Pillars of Islam. Meanwhile, the number of poles that cross from West to East is 6 as a symbol of the articles of Faith. The poles that prop the house can be interpreted as life support. The religious symbols found in the Karampuang traditional house can be interpreted that the Karampuang community highly considers religion as a pillar to support their lives in the world.

\section{Ladder.}

The Karampuang traditional house only has one Ladder. The placement of the ladder is different from the traditional house in South Sulawesi or other areas in Indonesia. In South Sulawesi, in general, the placement of a ladder is on the side or in front of that protrudes outward. However, in the Karampuang traditional house, the ladders are placed inside or in the middle of the house. The placement of the ladders is symbolized women as woman leaders in the history of Karampuang custom are exceedingly sacred. The position of the ladder in the one Karampuang traditional house must not be the same as the others. Such form also happens to Gella's traditional house. In South Sulawesi, in general, the placement of a ladder on the side or in front of that protrudes outward. However, in the Karampuang traditional house, the ladders are placed inside or in the middle of the house. The number of stepladders in the Karampuang traditional house must be odd. The position of the ladder in the Karampuang traditional house must not be the same as the position of the ladder in the houses of the others. The placement of the ladders cannot be separated from the female symbol. The ladder is symbolized as a reproductive tool for women as a source of life.

\section{House door.}

The door of the Karampuang traditional house is located at the front. The position of the door is parallel right against the floor of the house (salima') so that it must be lifted to enter the house. Above the door is a stone that functions as a counterweight so as the door can be partially or completely open. In the history of the Karampuang custom, they symbolize the stone as one of the reproductive organs for a woman.

\section{House floor.}


The floor of the Karampuang traditional house is made of bamboo, which is cut into small pieces called Salima' as a symbol of ribs. The bamboos are placed in this araseng stretching from north to south which is subsequently called tunebbe'. The bamboo strips are tied with a tampeng that stretches from east and west and starts from south to north. The tempeng in the Karampuang traditional belief is a symbol of a human vein. The tampeng bond should not be replaced with nails; therefore, even in the Karampuang traditional house, reinforcement from nails or wire will not be found. According to Arung, along with the times, the tampeng has been replaced with a rope made of a strong plastic material.

\section{Kitchen.}

Unlike the general traditional houses in South Sulawesi, where the kitchen is located at the back of the house, in the Karampuang traditional house, the kitchen is located at the front, which can be seen clearly when climbing the ladder. In front of the door is a kitchen with two stoves. These two stoves are symbolized as breasts in women. The kitchen in front is for welcoming anyone who comes to visit the house. The kitchen located at the front for the Karampuang community means openness to blissfully accept anyone who comes to visit the Karampuang traditional house, either the people living around the customary area or those from outside the Karampuang.

\section{Division of Space.}

The division of spaces of the traditional Karampuang house consists of beakung, sonrong ri olo, elle '/ lontang ri olo, elle' ri tengnga, elle 'ri monri, and sonrong ri monri. What distinguishes Arung's house from Gella's is the number of bili ' (rooms) in the sonrong ri monri section. At the Arung house, there are four bili' each for Arung, Sanro, Guru and Ana' Malolo Arung' while, in Gella's house, there are only two bili' which are occupied by Gella and Ana' Malolo Gella. In each of these space divisions, some rooms have their respective functions. Paruhung as the front room is an additional kitchen area that functions to store food ingredients. Sonrong is an area with room in it that functions as a place to give birth and as a place to receive guests. Elle'/lontang ri olo is a part of the house which is included in the ale bola to kitchen facing the door and another room as a place to receive public guests. Elle' ri tengnga is a part of the house that also functions to receive guests, to bathe, and to lay the corpse. Elle' ri monri is the part of the house with a space to prepare for traditional parties and marriage. And sonrong ri monri is situated at the back part of the house consisting of several rooms. Vertically, the division of space in the Karampuang traditional house is divided into three levels, to wit: rakkeang as a place to store rice and metal/iron tools, ale Bola as a place to live, and paratiwi as a place to keep livestock. In the house on stilts, in general, the boundary happens between awa Bola and ale Bola consists of alliri, pattolo riawa, and araseng. Meanwhile, in the Karampuang traditional house, pattolo riawa and pattolo riase are not found.

\section{The boundary between ale bola and rakkeang in the Karampuang traditional house is sameng which also functions as a rakkeang.}

For the people of Karampuang, sameng is the under house from the house in boting langi as a place to store rice known sangiasseri and as a place to store sharp objects. To strengthen the floor, consisting of salima or bamboo slats, the floor is divided into 12 areas which means 12 gellareng formed by the brothers of Manurungnge Ri Karampuang who left Karampuang to become kings elsewhere. These 12 areas are reinforced with Padongko. Also, the 12-floor means openness to receive guests from anywhere. Besides those 12-floor at the bottom part, there are six floors that are elevated named lontang I and V as a symbol of the six Manurungnge brothers who went on to form a kingdom elsewhere and held the mandate to each form two gellareng so that 12 gella were formed symbolized by the 12 floors mentioned. 
The boundary between ale bola and rakkeang in the Karampuang traditional house is sameng which also functions as a rakkeang.

To Karampuang's people, sameng means the under house from the house in boting langi, which besides functioning as a place to store rice symbolized as sangiasseri, it is also for a place to store sharp objects. There is hare' as a reinforcement for house poles. There are five hares in Karampuang 'traditional houses as a symbol of five times facing the Qibla through day and night for Muslims. Hare' is a round wood that is placed at the end of the top of the house poles and is the same length as the wood for the roof frame of the house.

\section{CONCLUSION AND FURTHER RESEARCH}

Based on research and discussion related to the analysis of the interpretation of the meaning of the Karampuang traditional house, the following conclusions can be indicated: 1 . The Karampuang traditional house has symbols of both verbal and nonverbal traditional houses along with the accompanying meanings that are believed from generation to generation. The meaning attached to these symbols cannot be separated from the history of Karampuang with women as leaders and Islam as a religion that affects the lives of the Karampuang people as well as the religious functions and social interaction functions that inherent in the Karampuang traditional house 2. The meaning contained in the symbols of Karampuang traditional houses has been held firmly from generation to generation by the Karampuang indigenous people. They believe that there is a philosophy of life behind those meanings that they should practice as guidelines in living life in this world and as provisions for the hereafter life.

\section{REFERENCES}

Abdul Mufti Radja, Ria Wikantari. 2016. Simbolisme Dalam Arsitektur Vernakular Karampuang-Sinjai Sulawesi Selatan. Prosiding Temu Ilmiah IPLBI.

Al-Tsagafa, Vol 15, No 2 (2018), Jurnal -Ilmiah Peradaban Islam, ISSNP (Online):26544598

Amrin H.Kanda. 2018. Representasi Makna Simbolik Rumah Adat Sasadu (Studi Etnografi Komunikasi Budaya Etnik Sahu di Kabupaten Halmahera Barat), Tesis. Makassar: Program Pascasarjana Ilmu Komunikasi - UNHAS.

Andi Wiwi Pratiwi Puji Lestari. 2014. Makna Simbolik Dalam Proses Mattompang Arajang di Kabupaten Bone, Skripsi. Makassar.

Bungin, Burhan. 2011. Penelitian Kualitatif. Kencana. Jakarta

Creswell, John W. 2007. Qualitative Inquiry \& Research Design: Choosing Among Five Approaches (2nd Edition). Sage Publications. USA.

Dadi Ahmadi, 2008. Interaksi Simbolik: Suatu Pengantar. Mediator, Vol.9 No.2.

Devito, J. A. 1997. Human Communication (Komunikasi Antar Manusia) Edisi Kelima. Profesional Books. Jakarta.

Heri Jauhari. 2018. Makna dan Fungsi Upacara Adat Nyangku Bagi Masyarakat Panjalu. Skripsi.

Hidayatullah. 2018. Analisis Makna Simbolik Budaya Sadaka Masyarakatdewan Adat Gorontalo. Tesis.

Klopf, Donald W. Intercultural Encounters. Morton Publishing Company. Colorado.

Knapp, M. L. 1972. Nonverbal Communication in Human Interaction. Holt, Rinehart and Winston, Inc. New York.

Koentjaraningrat. 2009. Pengantar Ilmu Antropologi. PT. Rineka Cipta. Jakarta. Liliweri Alo. 2009. Makna Budaya Dalam Komunikasi Antar Budaya. Lkis. Yogyakarta. Littlejohn, Stephen W dan Karen A.Foss. 2017. Theories Of Human Communication, Waveland Press, Inc. Moleong, Lexy J. 2010. Metodologi Penelitian Kualitatif. PT. Remaja Rosdakarya. Bandung.

Muhannis. 2009. Karampuang dan Bunga Rampai Sinjai. Pustaka Timur. Yogyakarta.

Mulyana, Deddy. 2003. Ilmu Komunikasi: Suatu Pengantar. PT Remaja Rosdakarya. Bandung.

Nur Rezki Awaliah, dkk. 2020. Kearifan Lokal Paseng Ri Ade' dan Pemberdayaan Masyarakat Adat Karampuang Dalam Upaya Pelestarian Hutan. La Geografia (Online), Vol.18 No.3. 
Ryan Prayogi, Endang Danial. 2016. Pergeseran Nilai-Nilai Budaya Pada Suku Bonai Sebagai Civic Culture Di Kecamatan Bonai Darussalam Kabupaten Rokan Hulu Provinsi Riau. HUMANIKA Vol. 23 No. 1 (2016) ISSN 1412-9418.

Samovar, Larry A. 2010. Komunikasi lintas Budaya. Salemba Humanika. Jakarta.

Samovar, Larry A, Richard E.Porter, 2005, Understanding Intercultural Communication. Belmont California A Division Of Wardword Inc.

Sobur, Alex. 2003. Semiotika Komunikasi. PT Remaja Rosdakarya. Bandung.

Sugiyono. 2006. Statistika Untuk Penelitian. Alfabeta. Bandung.

Wafa Nursiham. 2018. Etnis Sunda di Lereng Gunung Bawakaraeng. Tesis.

West Richard \& H.Turner Lynn. 2008. Pengantar Teori Komunikasi: Analisis dan Aplikasi. Salemba Humanika. Jakarta

Wirawan,I.B. 2012. Teori-teori Sosial Dalam Tiga Paradigma. Penerbit Kencana. 